\author{
I. Mironyuk ${ }^{1}$, M. Myslin ${ }^{1}$, I. Lapchuk ${ }^{1}$, T. Tatarchuk ${ }^{1}$, O. Olkhovy ${ }^{2}$
}

\title{
Adsorption of Azo Dye Congo Red on the Sn-Doped $\mathrm{TiO}_{2}$ Surface
}

\author{
${ }^{l}$ Vasyl Stefanyk Precarpathian National University, Ivano-Frankivsk, Ukraine, marjanysik@ gmail.com \\ 'Jagiellonian University, Kraków, Poland, oolkhovyi@gmail.com
}

\begin{abstract}
In this paper, the effect of $\mathrm{SnO}_{2}$ impurity on the surface charge and adsorption properties of $\mathrm{TiO}_{2} \mathrm{Samples}$ is investigated. The experimental value of the zero charge point for $\mathrm{TiO}_{2}$ with $3 \%, 6 \%$ and $12 \%$ of $\mathrm{SnO}_{2}$ equals $3.53,3.97$ and 3.2, respectively. The adsorption activity of the samples was studied on model solutions of the anionic dye - Congo red. The maximum adsorption capacity ( $\mathrm{q}_{\mathrm{exp}}$ ) equals $24.6 \mathrm{mg} / \mathrm{g}$ for $3 \mathrm{Sn} / \mathrm{TiO}_{2}, 25.0 \mathrm{mg} / \mathrm{g}$ for $6 \mathrm{Sn} / \mathrm{TiO}_{2}$ and $39.1 \mathrm{mg} / \mathrm{g}$ for $12 \mathrm{Sn} / \mathrm{TiO}_{2}$. Langmuir, Freundlich, and Dubinin-Radushkevich models were used to describe the adsorption mechanism of Congo red dye on the surface of $\mathrm{Sn} / \mathrm{TiO}_{2}$ samples. Based on the results of the studies of Congo red adsorption by the surface of titanium dioxide doped with Sn, all samples agree best with the Langmuir model. The correlation coefficients for the Langmuir isotherms are in the range of $0.9927-0.9996$, while the values of $\mathrm{R}^{2}$ for the Freundlich and Dubinin-Radushkevich isotherms are in the range of $0.721-0.8329$ and $0.8283-0.9433$, respectively. The low correlation of the experimental data with the Freundlich model indicates that these samples are not characterized by multilayer adsorption and inhomogeneous adsorbent surface. The results of approximation (Dubinin-Radushkevich model) indicate that the process of binding Congo red molecules to the $\mathrm{Sn} / \mathrm{TiO}_{2}$ surface is ion exchange, since the adsorption energy (E) is in the range of $8-$ $16 \mathrm{~kJ} \cdot \mathrm{mol}^{-1}$. Experimental data obtained from adsorption isotherms show that the $\mathrm{TiO}_{2}$ sample containing $12 \%$ $\mathrm{SnO}_{2}$ is the most active. The introduction of additional $\mathrm{Sn}$ ions into the $\mathrm{TiO}_{2}$ structure appears to lead to an increase in the adsorption capacity and the efficiency of dye removal. The best result of Congo red removal occurred at a concentration of $\mathrm{C}_{\mathrm{o}}=5 \mathrm{mg} / 1$ ( $\%$ of removed dye $\approx 83 \%$ for $12 \mathrm{Sn} / \mathrm{TiO}_{2} ; 81 \%$ for $6 \mathrm{Sn} / \mathrm{TiO}_{2}$ and $71 \%$ for $3 \mathrm{Sn} / \mathrm{TiO}_{2}$ ). Therefore, the studied samples of $\mathrm{TiO}_{2}$ doped with $\mathrm{SnO}_{2}$ can be used as effective adsorbents of Congo red from aqueous solutions.
\end{abstract}

Keywords: $\mathrm{TiO}_{2}$, adsorption, Congo red, $\mathrm{pH}$ Pzc.

Received 12 July 2021; Accepted 30 August 2021.

\section{Introduction}

In the modern world, where science is constantly and rapidly developing, much attention is paid to the study of oxide nanomaterials with important chemical and physical properties. Titanium dioxide is one of the most popular nanocompounds [1], with diverse range of applications. $\mathrm{TiO}_{2}$ is a major component in the production of paints, pigments [2], cosmetics [3, 4], plastics [5], coatings [6,7], etc. Furthermore, titanium oxide is widely used on surfaces that are capable of selfcleaning, because these particles have excellent photocatalytic and antibacterial properties $[8,9]$. The high adsorption capacity of $\mathrm{TiO}_{2}$ ensures the removal of contaminants from the aquatic environment, which allows to solve problems with wastewater treatment [1014]. In addition, titanium dioxide has been studied in photocatalysis, in the manufacture of supercapacitors, sensor devices and batteries [15]. The wide range of applications of this oxide depends on the structural and morphological characteristics, the method of production, as well as the crystalline modification of $\mathrm{TiO}_{2}$.

In the environment, titanium dioxide is distributed in the form of such polymorphic modifications as rutile, anatase and brookite [16]. Each modification of $\mathrm{TiO}_{2}$ is characterized by certain deviations in the lattice, granting them different properties [17]. The most common modification of rutile crystallizes in tetragonal crystal system with the space group $\mathrm{P} 4_{2} / \mathrm{mnm}$, and the parameters of the unit cell are: $\mathrm{a}=4,559 \AA ; \mathrm{c}=2,959 \AA$ 
[18]. The cell structure consists of a Ti atom surrounded by six $\mathrm{O}$ atoms (octahedral configuration of $\mathrm{TiO}_{6}$ ) [19]. Under high temperature and pressure, $\mathrm{TiO}_{2}$ with polymorphic modification of rutile is considered the most thermodynamically stable compared to anatase and brookite, and is the most common in the production of white pigment $[5,16]$.

Similar to rutile, crystalline modification of anatase has a tetragonal unit cell with a space group - I $4_{1} / \mathrm{amd}$, and the parameters of the unit cell are: $\mathrm{a}=\mathrm{b}=3.782 \AA$; $\mathrm{c}=9.502 \AA$ [20]. The octahedra in the anatase are deformed, so this leads to a distortion of symmetry. The polymorphic modification of anatase is known to have less thermodynamic stability, so high temperatures will cause the irreversible conversion of these phases of anatase into more stable phases of rutile [21]. Considering the photocatalytic properties of anatase, it is the leader among the modifications of titanium oxide [17]. Hence the growing trend for using anatase in photocatalysis among scientists [22].

Brookite is a modification of $\mathrm{TiO}_{2}$ with orthorhombic structure and space group $\mathrm{Pbca}$, the cell parameters are: $\mathrm{a}=9,166 \AA ; \mathrm{b}=5,436 \AA[15,16]$. Brookite, like anatase, is metastable in terms of thermodynamics, so under certain conditions it is capable of irreversible conversion to rutile [23]. Beside three main common polymorphic modifications of titanium dioxide, there is a less common form - $\mathrm{TiO}_{2}$ (B). This modification is characterized by lower chemical activity and is represented by a monoclinic structure with a space group $\mathrm{C} 2 / \mathrm{m}$ [24]. $\mathrm{TiO}_{2}$ (B) is being studied and finds its application in the development of anodes for lithium-ion batteries [25], adsorption of heavy metals from drinking water [26], as well as in photocatalysis [27].

Since the problem of water pollution is currently crucial for society, the search for a method and materials that would effectively carry out water treatment is an urgent issue. In particular, the study of titanium oxide as an adsorbent to remove contaminants from water is of great interest among scientists [28-32]. For example, Vasylyeva et al. [33] demonstrated the adsorption of yttrium from aqueous solutions on the surface of $4 \mathrm{As}-\mathrm{TiO}_{2}$ Ta Nd/4As- $\mathrm{TiO}_{2}$. In this case, the value of the maximum adsorption capacity of $\mathrm{Nd} / 4 \mathrm{As}-\mathrm{TiO}_{2}$ in relation to yttrium is $24.8 \mathrm{mg} / \mathrm{g}$, and for $4 \mathrm{As}-\mathrm{TiO}_{2}$ this value equals $127 \mathrm{mg} / \mathrm{g}$. It was found that the sorption of yttrium depends on the concentration of $\mathrm{Y}$ salt as well as the acidity of the solution and the stirring time. Sharma et al. [34] used metal oxide monoliths $\mathrm{MnO}_{2}$ and $\mathrm{TiO}_{2}$ as adsorbents to remove heavy metals. Depending on the choice of PEG used as the agent controlling the structure of the nanomaterial, the values of the maximum adsorption capacity of $\mathrm{Pb}(\mathrm{II})$ and $\mathrm{Cd}(\mathrm{II})$ ranged from 769 - $857 \mathrm{mg} / \mathrm{g}$ and 667 - $770 \mathrm{mg} / \mathrm{g}$, respectively. Such results were obtained by adding $0.02 \mathrm{~g}$ of adsorbent to $100 \mathrm{ml}$ of metal ion solution $(\mathrm{C}=10-50 \mathrm{mg} / \mathrm{l})$, stirring at $200 \mathrm{rpm}$ and then determining the concentration of the solution.

Beside heavy metals, common water contaminants include organic dyes, which can cause skin diseases even at low concentrations. The scientific literature demonstrates a wide range of methods for removing dyes, while adsorption is effective and inexpensive. For example, Kamal et al. [35] used $\mathrm{TiO}_{2} / \mathrm{CS}-\mathrm{CMM}$ nanocomposite to extract the Thymol violet dye from wastewater. The maximum $\mathrm{q}_{\mathrm{e}}$ of the $\mathrm{TiO}_{2} / \mathrm{CS}-\mathrm{CMM}$ composite was found to equal $97.51 \mathrm{mg} / \mathrm{g}$. Since titanium dioxide exhibits good photocatalytic properties and has the ability to decompose dyes in the light, adsorption experiments were performed in the dark for the accuracy of the results. The adsorption of two azo dyes, Reactive Red 198 and Direct Green 99, on the surface of anatase, $\mathrm{TiO}_{2}-\mathrm{P} 25$ and carbon-modified $\mathrm{TiO}_{2}$, was described by Janus et al. [36]. The studies were performed at $30{ }^{\circ} \mathrm{C}$ while stirring at $150 \mathrm{rpm}$ for 4 hours, and the maximum concentration of azo dye solutions equaled $20 \mathrm{mg} / \mathrm{L}$. The results of this experiment revealed that the maximum adsorption capacity of the samples to remove the Direct Green 99 dye equals $97.09 \mathrm{mg} / \mathrm{g}$, and in case of Reactive Red 198, qe equals $42.55 \mathrm{mg} / \mathrm{g}$, which is half the first value. Studies show that introducing additional atoms (metal or non-metal) into the structure of titanium dioxide causes an increase in the specific surface area and adsorption capacity [37], and, as a result, the efficiency of removal of organic and inorganic substances increases. Thus, the aim of this study is to investigate the $\mathrm{TiO}_{2}$ samples doped with $\mathrm{SnO}_{2}$ as effective adsorbents of azo dye Congo red from aqueous solutions.

\section{Experimental}

\subsection{Synthesis of $\mathrm{Sn}-\mathrm{TiO}_{2}$}

Samples of $\mathrm{TiO}_{2}$ doped with $\mathrm{Sn}$ atoms were obtained via sol-gel synthesis. First, a solution of titanium precursor was prepared by hydrolysis of $\mathrm{TiCl}_{4}$ with the formation of the aquacomplex $\left[\mathrm{Ti}\left(\mathrm{OH}_{2}\right)_{6}\right]^{3+} \cdot 3 \mathrm{Cl}^{-}$. The modifying agent $\mathrm{SnCl}_{4}$ (3, 6 and 12 wt. \%) was added into a solution of $\mathrm{TiCl}_{4}$, diluting with water afterwards. The solution was maintained at $\mathrm{pH}=0.5-2$ with $\mathrm{NaOH}$, heated to $60-70^{\circ} \mathrm{C}$ and homogenized over 1 hour. During heating, the reaction medium became cloudy and matte white. This indicated the formation of very small particles of titanium (IV) oxide, which were separated from the dispersed medium by vacuum filtration. The precipitate was washed from $\mathrm{Na}^{+}$and $\mathrm{Cl}^{-}$ions with distilled water until neutral $\mathrm{pH}$, and dried at a temperature of $120-140{ }^{\circ} \mathrm{C}$. The dried $\mathrm{Sn} / \mathrm{TiO}_{2}$ samples were ground in a porcelain mortar.

\subsection{Adsorption studies}

\subsection{1 pHpzc determination}

The point of zero charge of the surface of the samples was obtained via $\mathrm{pH}$ drift method as follows: $15 \mathrm{~mL}$ of $\mathrm{NaCl}$ electrolyte solution with different $\mathrm{pH}$ values $(2,3,4,7,8$ and 10) were placed in boxes and added to $100 \mathrm{mg}$ of powders. The $\mathrm{pH}$ of the electrolyte was maintained with $0.1 \mathrm{M}$ of $\mathrm{HCl}($ at $\mathrm{pH}<7$ ) and $\mathrm{NaOH}$ (at $\mathrm{pH}>7$ ) solutions. The dispersions were stirred for 2 hours, ultrasonicated and kept at room temperature for 24 hours to establish an equilibrium $\mathrm{pH}$ value. Initial $\left(\mathrm{pH}_{\mathrm{i}}\right)$ and final $\left(\mathrm{pH}_{\mathrm{f}}\right)$ values of the solutions were measured and monitored using a $\mathrm{pH}$-meter with a silver chloride electrode. A plot of $\mathrm{pH}_{\mathrm{i}}(\mathrm{x})$ versus $\mathrm{pH}_{\mathrm{f}}(\mathrm{y})$ was 
made, and the $\mathrm{pH}_{\mathrm{PzC}}$ value was determined by interpolation to the point where $\mathrm{pH}_{\mathrm{f}}=\mathrm{pH}_{\mathrm{i}}$.

\subsubsection{Adsorption of Congo red}

The adsorption properties of $\mathrm{Sn} / \mathrm{TiO}_{2}$ samples were investigated in a neutral medium of dye solutions. To construct isotherms, $20 \mathrm{mg}$ of samples were added to $50 \mathrm{ml}$ of Congo red solution with different concentrations $\left(C_{o}=5,10,15,20,25,50,75,100,125\right.$ and $150 \mathrm{mg} / \mathrm{L})$. Conical flasks with the sample and the dye were closed with a silicone stopper, periodically shaken for 4 hours, and left for 24 hours to reach equilibrium. The study was performed at a temperature of $25^{\circ} \mathrm{C}$, using a thermostat. The concentration of CR dye was determined spectrophotometrically at $500 \mathrm{~nm}$ in cuvettes with $1=5 \mathrm{~cm}$ using a ULAB 102-UV spectrophotometer. The adsorption capacity $\left(\mathrm{q}_{\mathrm{e}}\right)$ and the dye removal efficiency (E) for $\mathrm{Sn} / \mathrm{TiO}_{2}$ adsorbents were calculated with formulas (1) and (2):

$$
\begin{gathered}
\mathrm{q}_{\mathrm{e}}=\left(\mathrm{C}_{\mathrm{o}}-\mathrm{C}_{\mathrm{e}}\right) * \mathrm{~V} / \mathrm{m}, \\
\mathrm{E}(\%)=\left[\left(\mathrm{C}_{\mathrm{o}}-\mathrm{C}_{\mathrm{e}}\right) / \mathrm{C}_{\mathrm{o}}\right] * 100 \%,
\end{gathered}
$$

where $\mathrm{q}_{\mathrm{e}}$ is adsorption capacity, in $\mathrm{mg}$ of dye per $1 \mathrm{~g}$ of dry adsorbent $(\mathrm{mg} / \mathrm{g}) ; \mathrm{C}_{\mathrm{o}}$ and $\mathrm{C}_{\mathrm{e}}$ are initial and equilibrium concentration of dye in the solution $(\mathrm{mg} / \mathrm{L})$; $\mathrm{V}$ is volume of the dye $(\mathrm{L}) ; \mathrm{m}$ is mass of the adsorbent (g).

\section{Results and discussion}

\section{1 pHpzc}

$\mathrm{pH}_{\mathrm{PZC}}$ characterizes and determines the information about surface charge. The zero charge point is the $\mathrm{pH}$ value at which the surface charge of the adsorbent equals zero. If the experimental results show that $\mathrm{pH}>\mathrm{pH}$ PzC, it indicates a negative surface charge of the material and the ability to attract and absorb cations. If $\mathrm{pH}<\mathrm{pH}$ PZC, the surface of the adsorbent acquires a positive charge and will attach anions.

In our case, the drift method [38] was used to determine the $\mathrm{pH}_{\mathrm{PZC}}$ of the samples $\left(3 \mathrm{Sn} / \mathrm{TiO}_{2}, 6 \mathrm{Sn} / \mathrm{TiO}_{2}\right.$ and $12 \mathrm{Sn} / \mathrm{TiO}_{2}$ ), and the dependence of $\mathrm{pH}$ (final) versus $\mathrm{pH}$ (initial) was plotted, as shown in Fig. 1.

According to the curve image, the values of the zero charge point are: 3.53 for $3 \mathrm{Sn} / \mathrm{TiO}_{2}, 3.97$ for $6 \mathrm{Sn} / \mathrm{TiO}_{2}$ and 3.2 for $12 \mathrm{Sn} / \mathrm{TiO}_{2}$. When adsorbed from a solution with a neutral $\mathrm{pH}$, the zero charge point of the three samples shifts to the acidic side, meaning $\mathrm{pH}>\mathrm{pHpzc}$. This indicates a possible negative charge on the surface of titanium dioxide doped with $\mathrm{Sn}$.

\subsection{Adsorption of Congo red dye: isotherm modeling \\ Determination of the adsorption capacity of $\mathrm{TiO}_{2}$ samples doped with $\mathrm{Sn}$ in relation to the anionic dye Congo red is described by the adsorption isotherms, presented in Fig. 2. The best results under following conditions $\left(\mathrm{T}=25{ }^{\circ} \mathrm{C} ; \mathrm{m}_{\text {sorbent }}=20 \mathrm{mg} ; \mathrm{V}_{\text {solution }}=50 \mathrm{~mL}\right.$; $\left.\mathrm{C}_{\mathrm{o}}(\mathrm{CR})=5-150 \mathrm{mg} / \mathrm{L}\right)$ are observed in titanium}

dioxide

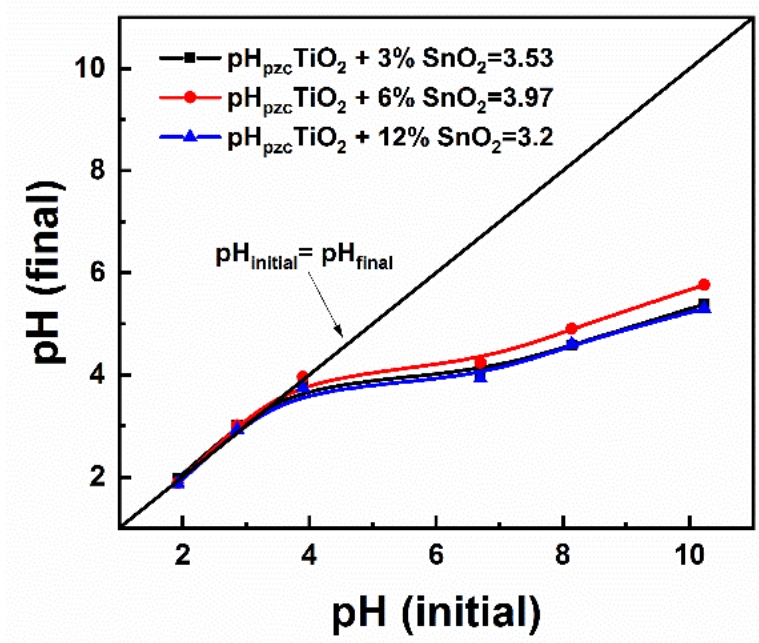

Fig. 1. Point of zero surface charge $\left(\mathrm{pH}_{\mathrm{PZC}}\right)$ values for $3 \mathrm{Sn} / \mathrm{TiO}{ }_{2}, 6 \mathrm{Sn} / \mathrm{TiO}_{2}$ and $12 \mathrm{Sn} / \mathrm{TiO}_{2}$.

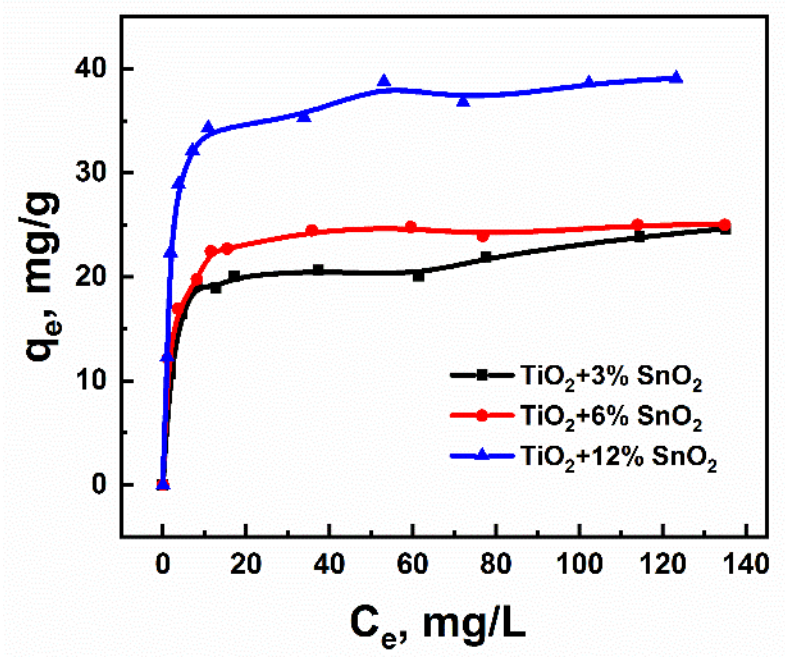

Fig. 2. Adsorption isotherms of Congo red on the surface of $\mathrm{Sn} / \mathrm{TiO}_{2}$ samples.

with the highest amount of Sn $12 \%$ ( $\left.\mathrm{q}_{\exp }=39.1 \mathrm{mg} / \mathrm{g}\right)$. Instead, the maximum adsorption capacity for samples with a lower percentage of metal $-3 \mathrm{Sn} / \mathrm{TiO}_{2}$ and $6 \mathrm{Sn} / \mathrm{TiO}_{2}$ is $24.6 \mathrm{mg} / \mathrm{g}$ and $25.0 \mathrm{mg} / \mathrm{g}$, respectively. The isotherms show that when the amount of $\mathrm{SnO}_{2}$ increases from $6 \%$ to $12 \%$, $\mathrm{q}_{\max }$ doubles. Based on the obtained experimental results, an increase in the percentage of $\mathrm{SnO}_{2}$ leads to an increase in the adsorption capacity of doped samples of titanium dioxide.

In this study, Langmuir, Freundlich and DubininRadushkevich models were used for a more detailed characterization of Congo red adsorption on the surface of $\mathrm{Sn} / \mathrm{TiO}_{2}$ samples. The Langmuir model is known to describe an adsorption process in which the adsorbate the absorbed substance (in our case, the Congo red dye) is concentrated on the surface of the adsorbent in only one layer. This model is also characterized by adsorption, which takes place on a homogeneous surface with the active centers present. The Langmuir isotherm (Fig. 3a) is expressed by the equation: $\mathrm{q}_{\mathrm{e}}=\left(\mathrm{q}_{\max } \mathrm{K}_{\mathrm{L}} \mathrm{C}_{\mathrm{e}}\right) /\left(1+\mathrm{K}_{\mathrm{L}} \mathrm{C}_{\mathrm{e}}\right)$, where $\mathrm{q}_{\max }$ is adsorption capacity; $\mathrm{K}_{\mathrm{L}}$ is constant of the 
Langmuir equation, $C_{e}$ is equilibrium concentration [39]. Based on the obtained results of adsorption studies, all the isotherms agree best with the Langmuir model.

Table 1 contains all the main parameters that confirm the Langmuir model to most adequately describe the adsorption of the dye on the surface of $3 \mathrm{Sn} / \mathrm{TiO}_{2}$, $6 \mathrm{Sn} / \mathrm{TiO}_{2}$ and $12 \mathrm{Sn} / \mathrm{TiO}_{2}$. For example, the correlation
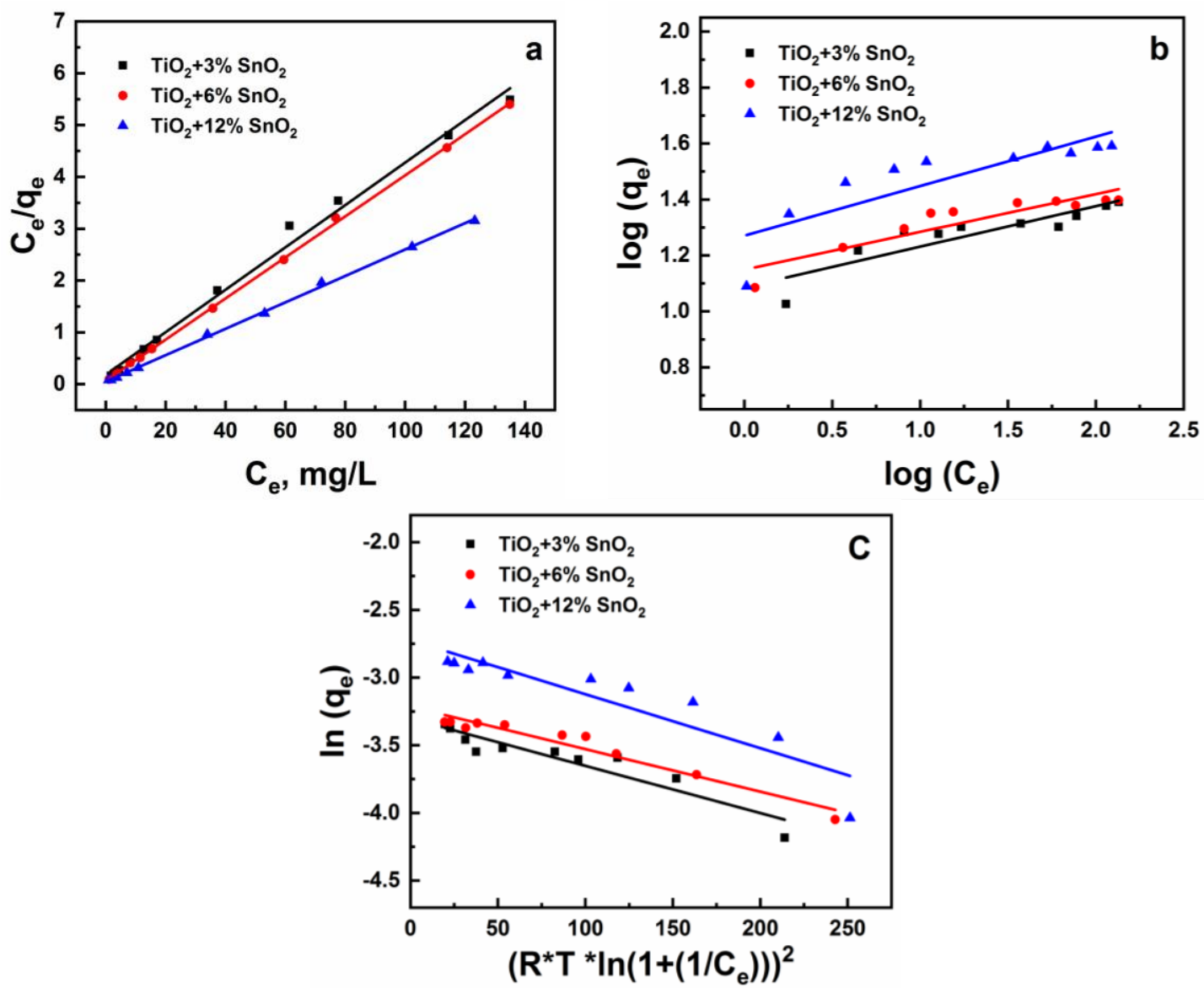

Fig. 3. Linear forms of Langmuir, Freundlich and Dubinin-Radushkevich models for the adsorption isotherms of Congo red on the surface of $\mathrm{Sn} / \mathrm{TiO}_{2}$ samples.

Table 1

Isotherm parameters of Langmuir, Freundlich and Dubinin-Radushkevich models for adsorption of Congo red on the surface of $3 \mathrm{Sn} / \mathrm{TiO}_{2}, 6 \mathrm{Sn} / \mathrm{TiO}_{2}$ and $12 \mathrm{Sn} / \mathrm{TiO}_{2}$ samples

\begin{tabular}{|c|c|c|c|}
\hline \multirow{2}{*}{ Model parameters } & \multicolumn{3}{|c|}{ Sample } \\
\hline & $3 \mathrm{Sn} / \mathrm{TiO}_{2}$ & $6 \mathrm{Sn} / \mathrm{TiO}_{2}$ & $12 \mathrm{Sn} / \mathrm{TiO}_{2}$ \\
\hline $\mathrm{q}_{\exp }, \mathrm{mg} / \mathrm{g}$ & 24.6 & 25.0 & 39.1 \\
\hline \multicolumn{4}{|c|}{ Langmuir isotherm } \\
\hline $\mathrm{q}_{\max }, \mathrm{mg} / \mathrm{g}$ & 24.5 & 25.3 & 39.2 \\
\hline $\mathrm{K}_{\mathrm{L}}$ & 0.22 & 0.58 & 0.50 \\
\hline $\mathrm{R}_{\mathrm{L}}$ & 0.03 & 0.01 & 0.14 \\
\hline $\mathrm{R}^{2}$ & 0.9927 & 0.9996 & 0.9991 \\
\hline \multicolumn{4}{|c|}{ Freundlich isotherm } \\
\hline $\mathrm{K}_{\mathrm{F}}$ & 12.2 & 14.1 & 18.7 \\
\hline $\mathrm{n}$ & 0.145 & 0.135 & 0.177 \\
\hline $\mathrm{R}^{2}$ & 0.8006 & 0.8329 & 0.721 \\
\hline \multicolumn{4}{|c|}{ Dubinin-Radushkevich isotherm } \\
\hline $\mathrm{q}_{\mathrm{m}}, \mathrm{mg} / \mathrm{g}$ & 25.6 & 28.0 & 45.7 \\
\hline $\mathrm{K}_{\mathrm{DR}}, \mathrm{mol}^{2} / \mathrm{kJ}^{2}$ & 0.004 & 0.003 & 0.004 \\
\hline $\mathrm{E}, \mathrm{kJ} \cdot \mathrm{mol}^{-1}$ & 11.95 & 12.7 & 11.2 \\
\hline $\mathrm{R}^{2}$ & 0.8795 & 0.9433 & 0.8283 \\
\hline
\end{tabular}




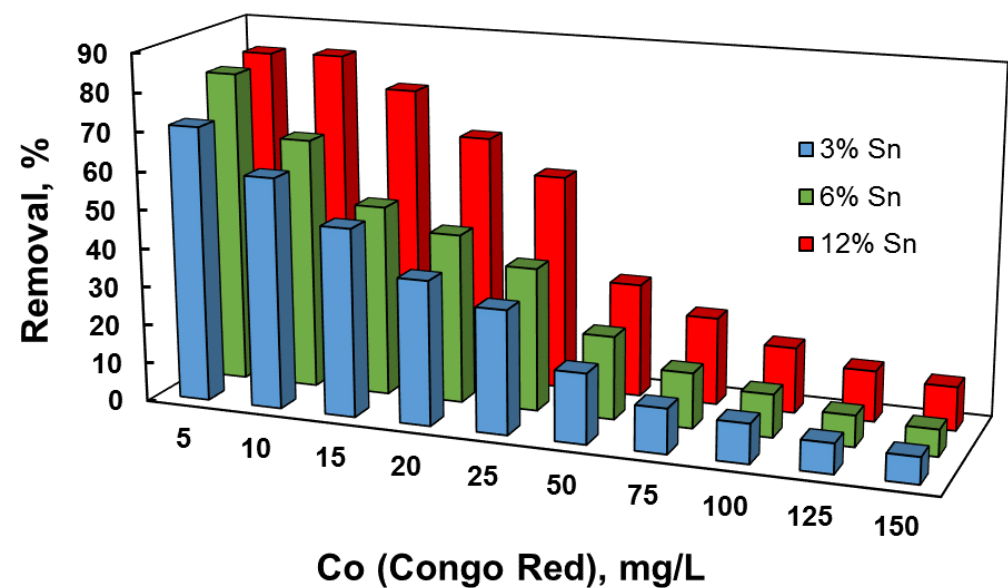

Fig. 4. Removal of Congo red $\left(\mathrm{C}_{\mathrm{o}}=5 \mathrm{mg} / \mathrm{L}-150 \mathrm{mg} / \mathrm{L}\right)$ from water medium by $3 \mathrm{Sn} / \mathrm{TiO}_{2}, 6 \mathrm{Sn} / \mathrm{TiO}_{2}$ and $12 \mathrm{Sn} / \mathrm{TiO}_{2}$ samples.

to other samples $\left(\mathrm{K}_{\mathrm{L}}=0.58\right)$. The dimensionless parameter $\mathrm{R}_{\mathrm{L}}$ was used to determine the type of adsorption isotherm. It described the adsorption of the dye on the surface of the doped titanium dioxide as favorable, because $0<\mathrm{R}_{\mathrm{L}}<1\left(\mathrm{R}_{\mathrm{L}}=0.03\right.$ for $3 \mathrm{Sn} / \mathrm{TiO}_{2}$, 0.01 for $6 \mathrm{Sn} / \mathrm{TiO}_{2}$ and 0.14 for $12 \mathrm{Sn} / \mathrm{TiO}_{2}$ ) [13].

The Freundlich isotherm is presented in Fig. 3b (coordinates: $\log \mathrm{q}_{\mathrm{e}}-\log \mathrm{C}_{\mathrm{e}}$ ). The Freundlich model is described by the equation: $\mathrm{q}_{\mathrm{e}}=\mathrm{K}_{\mathrm{F}} \mathrm{Ce}^{1 / \mathrm{n}}$, where $\mathrm{K}_{\mathrm{F}}$ is equilibrium constant of the Freundlich equation; $1 / n$ is parameter that indicates the intensity of the adsorbent/adsorbate interaction [39]. The decrease in the correlation coefficient for the Freundlich model $\left(\mathrm{R}^{2}=\right.$ 0.8006 for $3 \mathrm{Sn} / \mathrm{TiO}_{2}, \mathrm{R}^{2}=0.8329$ for $6 \mathrm{Sn} / \mathrm{TiO}_{2}, \mathrm{R}^{2}=$ 0.721 for $12 \mathrm{Sn} / \mathrm{TiO}_{2}$ ) compared to the Langmuir model indicates the inconsistency of this model regarding the adsorption of Congo red on the surface of $\mathrm{Sn} / \mathrm{TiO}_{2}$. This proves that these samples are not characterized by multilayer adsorption and inhomogeneous adsorbent surface. The calculated parameter $\mathrm{n}$ (Table 1) demonstrates a favorable adsorption in all cases, because $\mathrm{n}<1$. Instead, the Freundlich equilibrium constant $\left(\mathrm{K}_{\mathrm{F}}\right)$ characterizes the affinity of the dye to the surface of titanium dioxide: the highest value is in the sample $12 \mathrm{Sn} / \mathrm{TiO}_{2}\left(\mathrm{~K}_{\mathrm{F}}=18.7\right)$, in other cases $\mathrm{K}_{\mathrm{F}}$ decreases with decreasing percentage of $\mathrm{SnO}_{2}$ in the substance $\left(\mathrm{K}_{\mathrm{F}}=\right.$ 14.1 for $6 \mathrm{Sn} / \mathrm{TiO}_{2} ; \mathrm{K}_{\mathrm{F}}=12.2$ for $3 \mathrm{Sn} / \mathrm{TiO}_{2}$ ).

In contrast to the two mentioned models, adsorption isotherms were also described by the DubininRadushkevich model for a more complete description of the adsorption mechanism (Fig. 3c). Isotherms constructed in the coordinates $\log \mathrm{q}_{\mathrm{e}}-$ $\left(\mathrm{RT}^{*} \ln \left(1+\left(1 / \mathrm{C}_{\mathrm{e}}\right)\right)\right)^{2}$ do not fully describe the adsorption of Congo red on the surface of titanium dioxide doped with $\mathrm{Sn}$, compared with the Langmuir model $\left(\mathrm{R}^{2}=\right.$ $0.8283-0.9433$ for Dubinin-Radushkevich model). The Dubinin-Radushkevich constant showed that $3 \mathrm{Sn} / \mathrm{TiO}_{2}$ and $6 \mathrm{Sn} / \mathrm{TiO}_{2}\left(\mathrm{~K}_{\mathrm{DR}}=0.004\right)$ are more affine adsorbents for dye removal. The Dubinin-Radushkevich model makes it possible to determine the nature of the process of binding Congo red molecules to the $\mathrm{Sn} / \mathrm{TiO}_{2}$ surface chemical or physical. For this purpose, the adsorption energy values are used $\left(\mathrm{E}=11.95 \mathrm{~kJ} \cdot \mathrm{mol}^{-1}\right.$ for $3 \mathrm{Sn} / \mathrm{TiO}_{2}$, $12.7 \mathrm{~kJ} \cdot \mathrm{mol}^{-1}$ for $6 \mathrm{Sn} / \mathrm{TiO}_{2}$ and $11.2 \mathrm{~kJ} \cdot \mathrm{mol}^{-1}$ for $12 \mathrm{Sn} / \mathrm{TiO}_{2}$ ). The results indicate that ion exchange is the process of absorption of Congo red by the surface of titanium dioxide doped with $\mathrm{Sn}$, because $\mathrm{E}$ is in the range of $8-16 \mathrm{~kJ} \cdot \mathrm{mol}^{-1}$.

The efficiency of dye removal from solutions is shown in the form of a diagram in Fig. 4. As observed, the best removal of Congo red occurred at $\mathrm{C}_{\mathrm{o}}=5 \mathrm{mg} / \mathrm{L}$ (\% of removed dye $\approx 83 \%$ for $12 \mathrm{Sn} / \mathrm{TiO}_{2} ; 81 \%$ for $6 \mathrm{Sn} / \mathrm{TiO}_{2}$ and $71 \%$ for $3 \mathrm{Sn} / \mathrm{TiO}_{2}$ ). Accordingly, with increasing concentration of the dye in the aqueous solution, the efficiency of its removal decreases. The diagram also shows that the Sn present in the structure of titanium dioxide has a significant effect on the adsorption properties in these samples. For example, the removal efficiency increases with increasing $\%$ of $\mathrm{Sn}: 3 \mathrm{Sn} / \mathrm{TiO}_{2}<$ $6 \mathrm{Sn} / \mathrm{TiO}_{2}<12 \mathrm{Sn} / \mathrm{TiO}_{2}$. Thus, the introduction of additional $\mathrm{Sn}$ ions into the structure of $\mathrm{TiO}_{2}$ leads to an increase in the adsorption capacity and the efficiency of dye removal.

\section{Conclusions}

The effect of isomorphic substitution of Ti atoms for Sn atoms (3, 6 and $12 \%$ (wt.)) in the structure of $\mathrm{TiO}_{2}$ on its surface and adsorption properties was investigated. The point of zero charge on the surface of the samples was measured using $\mathrm{pH}$ drift method. The experimental value of the zero charge point is 3.53 for $3 \mathrm{Sn} / \mathrm{TiO}_{2}, 3.97$ for $6 \mathrm{Sn} / \mathrm{TiO}_{2}$ and 3.2 for $12 \mathrm{Sn} / \mathrm{TiO}_{2}$. Adsorption activity was studied in the range of Congo red concentrations from $5 \mathrm{mg} / \mathrm{L}$ to $150 \mathrm{mg} / \mathrm{L}$ at $25^{\circ} \mathrm{C}$ and in neutral $\mathrm{pH}$. The maximum adsorption capacity ( $\mathrm{q}_{\mathrm{exp}}$ ) equals 24.6 $\mathrm{mg} / \mathrm{g}$ for $3 \mathrm{Sn} / \mathrm{TiO}_{2}, 25.0 \mathrm{mg} / \mathrm{g}$ for $6 \mathrm{Sn} / \mathrm{TiO}_{2}$ and 39.1 $\mathrm{mg} / \mathrm{g}$ for $12 \mathrm{Sn} / \mathrm{TiO}_{2}$. Langmuir, Freundlich, and DubininRadushkevich models were used to describe the adsorption mechanism of Congo red on the surface of $\mathrm{Sn} / \mathrm{TiO}_{2}$ samples. The best result of Congo red removal occurred at a concentration of $\mathrm{C}_{\mathrm{o}}=5 \mathrm{mg} / \mathrm{L}$ (\% of sremoved dye $\approx 83 \%$ for $12 \mathrm{Sn} / \mathrm{TiO}_{2} ; 81 \%$ for $6 \mathrm{Sn} / \mathrm{TiO}_{2}$ and $71 \%$ for $3 \mathrm{Sn} / \mathrm{TiO}_{2}$ ). Synthesized samples can be 
effective adsorbents of organic dyes for water purification.

\section{Acknowledgements}

The authors thank the Ministry of Education and Science of Ukraine for financial support in the framework of project number 0120 U102035.
Mironyuk I. - Professor, Doctor of Chemistry Science, Head of the Chemistry Department;

Myslin M. - MSc, engineer of the Chemistry Department;

Lapchuk I. - Master student, Chemistry Department; Tatarchuk T. - PhD in Chemistry, Associate Professor of the Chemistry Department, Director of Educational and Scientific Center of Material Science and Nanotechnology;

Olkhovyy $\boldsymbol{O} .-5^{\text {th }}$ year student, Faculty of Pharmacy

[1] F. Xu, Chemosphere 212, 662 (2018); https://doi.org/10.1016/j.chemosphere.2018.08.108.

[2] G. Pfaff, P. Reynders, Chem. Rev. 99, 1963 (1999); https://doi.org/10.1021/cr970075u.

[3] H.J. Leong, S.G. Oh, J. Ind. Eng. Chem. 66, 242 (2018); https://doi.org/10.1016/j.jiec.2018.05.035.

[4] A. Weir, P. Westerhoff, L. Fabricius, K. Hristovski, N. Von Goetz, Environ. Sci. Technol. 46, 2242 (2012); https://doi.org/10.1021/es204168d.

[5] Y. Liang, H. Ding, J. Alloys Compd. 844, 156139 (2020); https://doi.org/10.1016/j.jallcom.2020.156139.

[6] J. George, C.C. Gopalakrishnan, P.K. Manikuttan, K. Mukesh, S. Sreenish, Powder Technol. 377, 269 (2021); https://doi.org/10.1016/j.powtec.2020.08.050.

[7] L. Zheng, S. Qian, X. yong Liu, Trans. Nonferrous Met. Soc. China (English Ed. 30, 171 (2020); https://doi.org/10.1016/S1003-6326(19)65189-7.

[8] A.J. Haider, R.H. Al-Anbari, G.R. Kadhim, C.T. Salame, Energy Procedia. 119, 332 (2017); https://doi.org/10.1016/j.egypro.2017.07.117.

[9] S. Riaz, S.J. Park, J. Ind. Eng. Chem. 84, 23 (2020); https://doi.org/10.1016/j.jiec.2019.12.021.

[10] I. Mironyuk, I. Mykytyn, H. Vasylyeva, K. Savka, J. Mol. Liq. 316, 113840 (2020); https://doi.org/10.1016/j.molliq.2020.113840.

[11] M.M. Dávila-Jiménez, M.P. Elizalde-González, M.A. Guerrero-Morales, J. Mattusch, Process Saf. Environ. Prot. 120, 195 (2018); https://doi.org/10.1016/j.psep.2018.09.012.

[12] K.A. Gebru, C. Das, J. Water Process Eng. 16, 1 (2017); https://doi.org/10.1016/j.jwpe.2016.11.008.

[13] I. Mironyuk, T. Tatarchuk, M. Naushad, H. Vasylyeva, I. Mykytyn, J. Mol. Liq. 285, 742 (2019); https://doi.org/10.1016/j.molliq.2019.04.111.

[14] N. Danyliuk, T. Tatarchuk, K. Kannan, A. Shyichuk, Water Sci. Technol. 00, 1 (2021); https://doi.org/10.2166/wst.2021.236.

[15] N. Rahimi, R.A. Pax, E.M. Gray, Prog. Solid State Chem. 44, $86 \quad$ (2016); https://doi.org/10.1016/J.PROGSOLIDSTCHEM.2016.07.002.

[16] M.A. Vargas, J.E. Rodríguez-Páez, J. Non. Cryst. Solids. 459, $192 \quad$ (2017); https://doi.org/10.1016/j.jnoncrysol.2017.01.018.

[17] H. Kurban, M. Dalkilic, S. Temiz, M. Kurban, Comput. Mater. Sci. 183, 109843 (2020); https://doi.org/10.1016/j.commatsci.2020.109843.

[18] G. Meinhold, Earth-Science Rev. 102, 1 (2010); https://doi.org/10.1016/j.earscirev.2010.06.001.

[19] U. Diebold, <(Surf.Sci.Rep.)[2003]The surface science of titanium dioxide.pdf>, Surf. Sci. Rep. 48, 53 (2002).

[20] W.J. Yin, B. Wen, C. Zhou, A. Selloni, L.M. Liu, Surf. Sci. Rep. 73, 58 (2018); https://doi.org/10.1016/j.surfrep.2018.02.003.

[21] S. Jafari, M. Sillanpää, Elsevier Inc. 85( 2020); https://doi.org/10.1016/b978-0-12-819216-0.00002-3.

[22] R. Katal, S. Masudy-Panah, M. Tanhaei, M.H.D.A. Farahani, H. Jiangyong, Chem. Eng. J. 384, 123384 (2020); https://doi.org/10.1016/j.cej.2019.123384.

[23] K.C. Christoforidis, P. Fornasiero, Photocatalytic Mater. 127 (2020); https://doi.org/10.1016/b978-0-12819000-5.00009-6.

[24] P. Mikrut, M. Kobielusz, P. Indyka, W. Macyk, Mater. Today Sustain. 10, 100052. (2020); https://doi.org/10.1016/j.mtsust.2020.100052.

[25] D.P. Opra, S. V. Gnedenkov, S.L. Sinebryukhov, J. Power Sources. 442, 227225 (2019); https://doi.org/10.1016/j.jpowsour.2019.227225.

[26] A. Sarkar, B. Paul, J. Mol. Liq. 2, 114556 (2020); https://doi.org/10.1016/j.molliq.2020.114556.

[27] K.K. Paul, R. Ghosh, P.K. Giri, Nanotechnology 27, 1 (2016); https://doi.org/10.1088/09574484/27/31/315703.

[28] G. Zhou, Y. Cao, Y. Jin, C. Wang, Y. Wang, C. Hua, S. Wu, Novel selective adsorption and photodegradation of BPA by molecularly imprinted sulfur doped nano-titanium dioxide, J. Clean. Prod. 274 (2020) 122929. doi:10.1016/j.jclepro.2020.122929.

[29] [29] Y. Wang, Y. Guan, Y. Li, Z. Li, J. Wan, Y. Zhang, J. Fu, Process Saf. Environ. Prot. (2020); https://doi.org/10.1016/j.psep.2020.10.036.

[30] I. Mironyuk, T. Tatarchuk, H. Vasylyeva, M. Naushad, I. Mykytyn, J. Environ. Chem. Eng. 7, 103430 (2019); https://doi.org/10.1016/j.jece.2019.103430. 
[31] I. Mironyuk, T. Tatarchuk, H. Vasylyeva, V.M. Gun'ko, I. Mykytyn, J. Mol. Liq. (2019); https://doi.org/10.1016/j.molliq.2019.03.026.

[32] T. Tatarchuk, A. Shyichuk, I. Mironyuk, M. Naushad, J. Mol. Liq. 293, 111563 (2019); https://doi.org/10.1016/j.molliq.2019.111563.

[33] H. Vasylyeva, I. Mironyuk, I. Mykytyn, K. Savka, Appl. Radiat. Isot. 109473 (2020); https://doi.org/10.1016/j.apradiso.2020.109473.

[34] M. Sharma, D. Choudhury, S. Hazra, S. Basu, J. Alloys Compd. 720, 221 (2017); https://doi.org/10.1016/j.jallcom.2017.05.260.

[35] T. Kamal, Y. Anwar, S.B. Khan, M.T.S. Chani, A.M. Asiri, Carbohydr. Polym. 148, 153 (2016); https://doi.org/10.1016/j.carbpol.2016.04.042.

[36] M. Janus, E. Kusiak, J. Choina, J. Ziebro, A.W. Morawski, Desalination 249, 359 (2009); https://doi.org/10.1016/j.desal.2009.04.013.

[37] S. Ashraf, A. Siddiqa, S. Shahida, S. Qaisar, Heliyon 5, e01577 (2019); https://doi.org/10.1016/J.HELIYON.2019.E01577.

[38] T. Tatarchuk, N. Paliychuk, R.B. Bitra, A. Shyichuk, M.U. Naushad, I. Mironyuk, D. Ziółkowska, Desalin. Water Treat. 150, 374 (2019); https://doi.org/10.5004/dwt.2019.23751.

[39] T. Tatarchuk, M. Myslin, I. Mironyuk, M. Bououdina, A.T. Pędziwiatr, R. Gargula, B.F. Bogacz, P. Kurzydło, J. Alloys Compd. 819, (2020); https://doi.org/10.1016/j.jallcom.2019.152945.

\title{
I. Миронюк ${ }^{1}$ М. Мислін ${ }^{1}$, І. Лапчук ${ }^{1}$, Т. Татарчук ${ }^{1}$, О. Ольховий ${ }^{2}$
}

\section{Адсорбція азобарвника Конго-червоного на поверхні $\mathrm{TiO}_{2}$, легованій $\mathrm{Sn}$}

\author{
${ }^{1}$ Прикарпатський начіональний університет імені Василя Стефаника, Івано-Франківськ, Украӥна, тагјапуsik@gmail.com \\ ${ }^{2}$ Ягеллонський університет, Краків, Польща, oolkhovyi@gmail.com
}

\begin{abstract}
У роботі досліджено вплив домішки $\mathrm{SnO}_{2}$ на поверхневий заряд та адсорбційні властивості зразків $\mathrm{TiO}_{2}$. Експериментальне значення точки нульового заряду для $\mathrm{TiO}_{2} 33 \%, 6 \%$ та $12 \% \mathrm{SnO}_{2}$ дорівнює 3,53, 3,97 та 3,2 відповідно. Адсорбційну активність зразків вивчали на модельних розчинах аніонного барвника - Конго червоного. Максимальна адсорбційна здатність (qехр) дорівнює 24,6 мг/г для $3 \mathrm{Sn} / \mathrm{TiO}_{2}$, $25,0 \mathrm{мг} / \Gamma$ для $6 \mathrm{Sn} / \mathrm{TiO}_{2}$ та $39,1 \mathrm{мг} / \Gamma$ для $12 \mathrm{Sn} / \mathrm{TiO}_{2}$. Для опису механізму адсорбції барвника Конго червоного на поверхні зразків $\mathrm{Sn} / \mathrm{TiO}_{2}$ використовували моделі Ленгмюра, Фрейндліха та ДубінінаРадушкевича. На основі результатів досліджень адсорбції Конго червоного поверхнею легованого діоксиду титану встановлено, що всі зразки найкраще узгоджуються з моделлю Ленгмюра. Коефіцієнти кореляції для ізотерм Ленгмюра знаходяться в межах $0,9927-0,9996$, тоді як значення $\mathrm{R}^{2}$ для ізотерм Фрейндліха та Дубініна-Радушкевича знаходяться в межах 0,721 - 0,8329 та 0,8283 - 0,9433 відповідно. Низька кореляція експериментальних даних 3 моделлю Фрейндліха свідчить про те, що ці зразки не характеризуються багатошаровою адсорбцією та неоднорідною поверхнею адсорбенту. Результати апроксимації (модель Дубініна-Радушкевича) вказують на те, що процес зв'язування молекул Конго червоного 3 поверхнею $\mathrm{Sn} / \mathrm{TiO}_{2} €$ іонним обміном, оскільки енергія адсорбції (Е) знаходиться в діапазоні 8 - 16 кДж·моль ${ }^{-1}$. Експериментальні дані, отримані за допомогою ізотерм адсорбції, показують, що зразок $\mathrm{TiO}_{2}$, що містить $12 \% \mathrm{SnO}_{2}, \epsilon$ найбільш активним. Введення додаткових іонів $\mathrm{Sn}$ у структуру $\mathrm{TiO}_{2}$ призводить до збільшення адсорбційної здатності та ефективності видалення барвника. Найкращий результат видалення Конго червоного спостерігався при концентрації $\mathrm{C}_{\mathrm{o}}=5 \mathrm{мг} /$ л (\% видаленого барвника $\approx 83 \%$ для $12 \mathrm{Sn} / \mathrm{TiO}_{2} ; 81 \%$ для $6 \mathrm{Sn} / \mathrm{TiO}_{2}$ та $71 \%$ для $3 \mathrm{Sn} / \mathrm{TiO}_{2}$ ). Отже, зразки $\mathrm{TiO}_{2}$, леговані $\mathrm{SnO}_{2}$, можуть бути використані як ефективні адсорбенти для видалення барвника Конго червоного з водних розчинів.

Ключові слова: $\mathrm{TiO}_{2}$, адсорбція, Конго червоний, рНтнз.
\end{abstract}

